\title{
Investigating maternity roost selection by northern long-eared bats at three sites in Wisconsin
}

\author{
Brenna A. Hyzy ${ }^{1,6}$, Robin E. Russell ${ }^{2, *}$, Alex Silvis ${ }^{3}$, W. Mark Ford ${ }^{4}$, Jason Riddle ${ }^{5}$, \\ Kevin Russell ${ }^{1,7}$ \\ ${ }^{1}$ College of Natural Resources, University of Wisconsin Stevens Point, Stevens Point, WI 54481, USA \\ ${ }^{2}$ U.S. Geological Survey, National Wildlife Health Center, Madison, WI 53705, USA \\ ${ }^{3}$ West Virginia Division of Natural Resources, Elkins, WV 26241, USA \\ ${ }^{4}$ U.S. Geological Survey, Virginia Cooperative Fish and Wildlife Research Unit, Blacksburg, VA 24061, USA \\ ${ }^{5}$ College of Natural Resources, University of Wisconsin Stevens Point, Stevens Point, WI 54481, USA \\ ${ }^{6}$ Present address: Western Ecosystems Technology, Inc., 7575 Golden Valley Rd, Suite 300, Golden Valley, MN 55427, USA \\ ${ }^{7}$ Present address: U.S. Fish and Wildlife Service, Arizona Ecological Services, 9828 North 31st Avenue \# C3, Phoenix, \\ AZ 85051-2517, USA
}

\begin{abstract}
One of the North American bat species most impacted by white-nose syndrome (WNS) is the northern long-eared bat Myotis septentrionalis, which as a result has been listed under the Endangered Species Act. WNS was first detected in Wisconsin in 2014. Unfortunately, little is known regarding the ecology of $M$. septentrionalis in this state pre-WNS to guide management supporting post-WNS recovery efforts. The objectives of our research were to (1) assess characteristics of trees that are associated with roost tree selection and (2) investigate how characteristics of maternity colony networks compare to colonies in the eastern USA. We mist-netted at 3 sites in Wisconsin in 2015 and 2016, and affixed radio transmitters to 39 female M. septentrionalis. We tracked bats to 53 confirmed day roosts. We found that roost trees were larger, more decayed, and more likely to be in dominant canopy closure areas than random trees. Oaks Quercus spp. were used most frequently and in proportion to their availability in the landscape at 2 field sites, whereas invasive black locust Robinia pseudoacacia was used more than expected based on availability at another site. Overall, minimum convex polygon sizes for maternity roosts were variable (5.2 to $8.9 \mathrm{ha}$ ) but similar to values reported for other regions. However, network centrality was low, indicating equitable use of day roosts and more frequent roost switching compared to other regions. Our findings provide information that increasing availability of potential day roosts in the landscape during the reproductive period may improve recruitment, which may in turn mitigate some of the detrimental population effects from WNS.
\end{abstract}

KEY WORDS: Day roost - Maternity network $\cdot$ Northern long-eared bat $\cdot$ Myotis septentrionalis Wisconsin $\cdot$ Upper Midwest $\cdot$ White-nose syndrome

\section{INTRODUCTION}

North American bats face multiple threats, including anthropogenic disturbances to the winter hibernacula of cave-dwelling bats, habitat loss and degradation, and wind energy impacts (i.e. wind turbine fatality) on migratory species (Jachowski et al. 2016).

*Corresponding author: rerussell@usgs.gov
Fully understanding North American bat habitat and community ecology has become critically important in recent years due to the negative effects of whitenose syndrome (hereafter WNS) caused by the fungal pathogen Pseudogymnoascus destructans (Blehert et al. 2009). In addition to the mass mortalities of bats caused by WNS during winter hibernation, it

(C) The authors and, outside the USA, the US Government 2020. Open Access under Creative Commons by Attribution Licence. Use, distribution and reproduction are unrestricted. Authors and original publication must be credited.

Publisher: Inter-Research · www.int-res.com 
has been hypothesized that forest disturbances (e.g. timber harvest) may contribute to the overall decline of bat populations by reducing the availability of maternal roost trees used by communal assemblages of female bats in the summer (Johnson et al. 2011). Currently, there is a need for region-specific data on habitat conditions associated with survival and recruitment of these sensitive bat species, given the impacts of WNS (Silvis et al. 2015a).

Historically, the northern long-eared bat Myotis septentrionalis (Trouessart, 1897) (hereafter MYSE) was among the most common bat species in North America, distributed across 37 eastern and northcentral US states, and in several Canadian provinces from the Atlantic coast to the Northwest Territories (Caceres \& Barclay 2000). The distribution of bats in eastern North America pre- and post-WNS, including MYSE, are affected by a variety of site- and landscape-level factors, including availability of prey, level of habitat fragmentation, and climate (Ford et al. 2006a, Silvis et al. 2012, Coleman et al. 2014, Pauli et al. 2015). MYSE can be found throughout Wisconsin and adjacent portions of the Upper Midwest, although the species is less common in the Upper Midwest relative to other portions of its range (Francl 2008). The MYSE range includes multiple regions and latitudes, and because of this distribution, roosts have been found in various types of forest (Lacki et al. 2009, Silvis et al. 2016). However, there has been little research on MYSE roosting ecology in the Upper Midwest (Foster \& Kurta 1999, Silvis et al. 2016).

Northern long-eared bats form non-random socially associating maternity colonies that consist mostly of related females during the maternity season (May to August) within cavities or under exfoliating bark of deciduous trees or snags (Foster \& Kurta 1999, Lacki \& Schwierjohann 2001, Perry \& Thill 2007, Garroway \& Broders 2008, Silvis et al. 2014, 2015b). In warmer, more southerly portions of its range, solar radiation is likely not a limiting factor for roost tree selection (Menzel et al. 2002). In contrast, MYSE within more northerly climates may establish maternal roost colonies in relatively open-canopied forests to facilitate thermoregulatory needs, especially after giving birth to a pup (Johnson et al. 2011, Silvis et al. 2012, Patriquin et al. 2016). Maternity colonies include 30 to 60 bats (Foster \& Kurta 1999). Occasionally, MYSE will form smaller temporary satellite groups composed of individuals from the main colony, potentially resulting in lower numbers of bats within individual day roosts but a larger area of overall spatial occupancy (Johnson et al. 2012, Silvis et al. 2014).
The females remain grouped in these colonies from late spring to late summer while pregnant, when giving birth, and when rearing their single pup to volancy (Caceres \& Barclay 2000).

In addition to the overall decline of MYSE, surviving populations of this species have suffered from poor juvenile recruitment since the onset of WNS (Francl et al. 2012, Reynolds et al. 2016). Therefore, the summer maternity season is now a major focus of conservation efforts designed to stabilize and recover populations of MYSE (Silvis et al. 2015a, Jachowski et al. 2016). Recent research has suggested that the identification and conservation of high-quality day roosts during the maternity period is particularly important for the growth and survivorship of new offspring, as well as successful adult survival (Kunz \& Lumsden 2003, Pauli et al. 2015). Accordingly, a section 4(d) rule under the Endangered Species Act (ESA) is currently in place that prohibits purposeful and incidental take within areas impacted by WNS that result from tree removal activities near known maternity roost trees or hibernacula. However, a lack of information in the Upper Midwest on specific characteristics of maternal roost colony sites prevents wildlife and forest managers from implementing effective measures to conserve the species in this region, particularly where mist-netting surveys have not occurred or the location of maternity colony day roosts is not known.

In eastern North America, the population and habitat ecology of MYSE is well studied. Several studies have been published on maternity roost selection (Sasse \& Pekins 1996, Lacki \& Schwierjohann 2001, Menzel et al. 2002, Jung et al. 2004, Perry \& Thill 2007, Henderson et al. 2008, Johnson et al. 2011, Silvis et al. 2012), colony social structure (Foster \& Kurta 1999, Willis \& Brigham 2004, Ford et al. 2006a, Silvis et al. 2014, 2015b), and predicted responses to forest management practices (Menzel et al. 2002, Ford et al. 2006b, Johnson et al. 2012, Silvis et al. 2014, Pauli et al. 2015). Currently in the Upper Midwest, there is a lack of information on the specific habitat ecology of MYSE (Silvis et al. 2012), in particular characteristics of maternal sites in Wisconsin and the surrounding region. This lack of information creates a gap in knowledge and precludes national-scale analyses of roost site selection to determine if regional differences occur. Moreover, it is still unclear whether dayroost availability within a stand is a significant influence on roost selection or social structure by MYSE, as roost use and social patterns vary widely among colonies and across regions (Silvis et al. 2012, 2015a,b, Jachowski et al. 2016). 
The objectives of our research were to (1) assess characteristics of trees that are associated with roost tree selection and (2) investigate how maternity colony networks and day-roost ecology compare to observed colonies in the Ohio River Valley and central Appalachian Mountains. We used methods similar to Silvis et al. (2012) and Ford et al. (2006a) to allow for consistency in data collection and interpretation and for comparable results (Silvis et al. 2015a,b).

\section{MATERIALS AND METHODS}

\subsection{Study areas}

We captured MYSE at 3 sites in Wisconsin to investigate maternity roost selection: Governor Dodge State Park, Sandhill Wildlife Area, and Black River State Forest (Fig. 1). These areas were chosen in an effort to sample a longitudinal slice of Wisconsin, resulting in a collective study area that included 1 site within the unglaciated portion of the state, 1 in the glaciated portion of the hardwood zone, and 1 within the hardwood/boreal 'tension' zone. Additionally, each of our study sites were areas of known MYSE presence based on historical Department of Natural Resources (DNR) records. Efforts to capture MYSE at the 3 sites focused on forest corridors, areas that had a

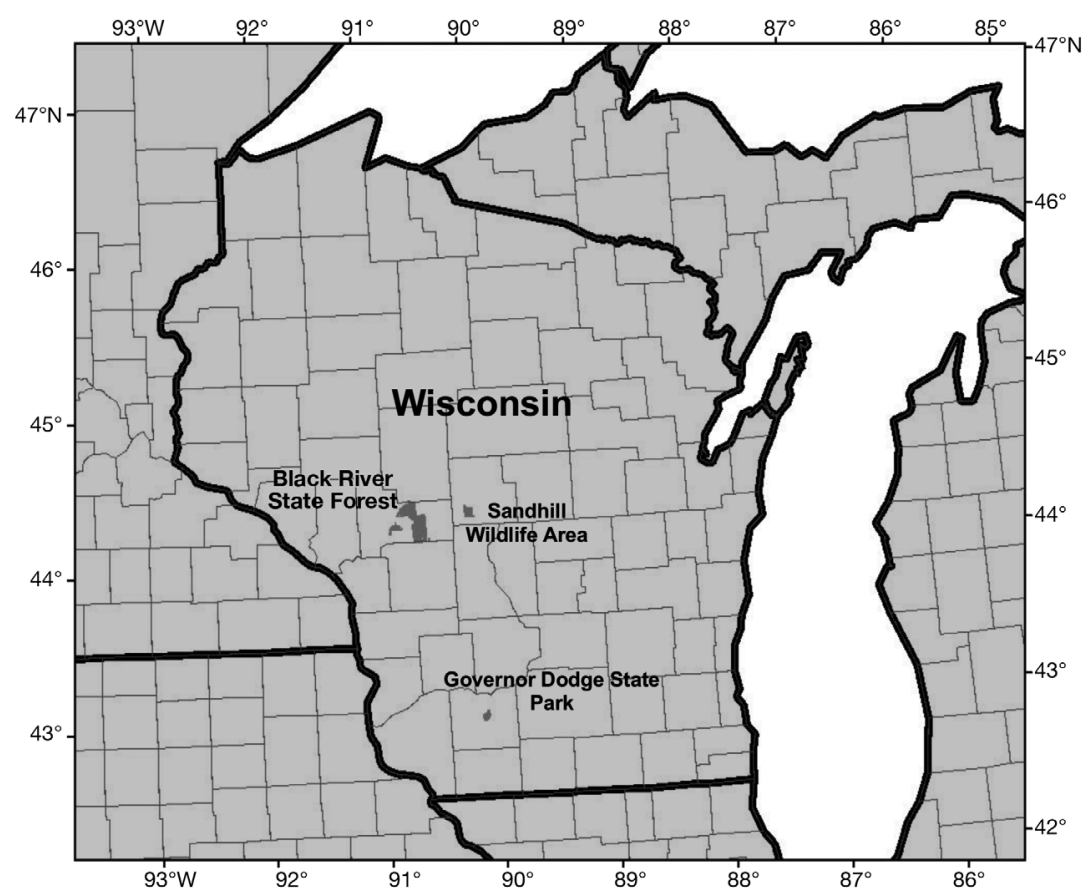

Fig. 1. Mist-net survey sites for northern long-eared bat Myotis septentrionalis day-roost tracking in Wisconsin, 2015 and 2016 high potential for acoustic detection success, and coordinates provided by the Wisconsin Department of Natural Resources (WDNR) where successful capture of MYSE had occurred in previous years.

Governor Dodge State Park (GD) is a 2165 ha property located $6.6 \mathrm{~km}$ north of Dodgeville, Iowa County, WI. The park is dominated by oak Quercus spp., hickory Carya spp., and mixed pine Pinus spp. forests, as well as open savanna and tallgrass prairies. This property is within an area that was not subject to the most recent glaciation. As a result, hills and valleys that are much less common across the rest of the state characterize the area. As this is a small State Park used primarily for recreation, the area is not managed under any specific silvicultural regime.

Sandhill Wildlife Area (SH) is a 3703 ha property located in southwestern Wood County, WI. The state acquired the property in 1962, and actively manages this area to maintain early successional forest and wetland wildlife habitat. The land lies within a bed of an ancient glacial lake formed from the runoff of the glaciers in Wisconsin, and the present-day site consists of flat, marshy land interspersed with oak and aspen stands. Oak wilt (caused by Ceratocystis fagacearum) has plagued Sandhill for the past $50 \mathrm{yr}$, and as a result, oak snags are currently abundant.

Black River State Forest (BR) is a 27519 ha state forest located in Jackson and Clark counties, $19 \mathrm{~km}$ south of Black River in west-central Wisconsin. Glaciation strongly influenced this area and the resulting topography includes buttes, hills, knolls, and ridges across the landscape. The area was originally dominated by red pine $P$. resinosa and white pine $P$. strobus until it was heavily logged from 1880 to 1895 . The state actively manages 31 stands comprising 1252 acres within the state forest $(68.5 \%$ of all state forest acreage) for biannual timber harvest with a combination of thinning and regeneration cuts. The dominant forest structure consists of jack pine $P$. banksiana, oaks, and aspen Populus spp.

\subsection{Field methods}

We conducted nightly bat surveys using mist nets (Bat Conservation and Management) to capture MYSE at each of the maternity roost sites (GD, $\mathrm{SH}$, and $\mathrm{BR}$ ). We captured bats between May and July of 2015 and 2016 to target females during 
the maternity season. Mist net deployment was dependent on the location being surveyed, but generally consisted of 1 or 2 Avinet polyester mist nets (6 to $12 \mathrm{~m}$ long, $7.3 \mathrm{~m}$ high, $38 \mathrm{~mm}$ mesh size) set across a forest corridor on a pulley system between 2 aluminum poles (Owen et al. 2002, Silvis et al. 2012). Netting concluded once a sufficient sample of female MYSE was captured ( $\mathrm{n}=15$ at each site) or after 3 consecutive weeks of netting. Nets were assembled and opened before sunset (approximately 20:00 h). Nightly netting continued until capture rates decreased to 1 bat every hour or until midnight (Central Standard Time).

For every bat captured, we recorded sex, age (by degree of epiphyseal fusion), mass ( $g$ ), right forearm length (RFA), and reproductive condition (Silvis et al. 2012). Unique lipped aluminum identification bands were attached on the left forearms of all female bats and right forearms of all male bats according to WDNR protocol. We also removed a small section of fur and affixed radio transmitters (LB-2X, $0.27 \mathrm{~g}$; Holohil Systems) between the scapulae of females using surgical cement (Perma-Type; Silvis et al. 2012). The $<6 \%$ of pre-attachment body weight (including transmitter and surgical glue) rule was followed when tagging individual females as required by the federal permit. Within 30 min of capture, bats were released within a few meters of the net site. All field and handling procedures followed guidelines of the Wisconsin Endangered and Threatened Species Permit \#1005 and the Federal Fish and Wildlife - Native Threatened Species Recovery permit \#TE86141B-0, and were approved by UWSP IACUC \#2015.04.05. Following federal protocol, all nets and equipment were decontaminated after each capture night using Lysol wipes and a 1:10 bleach solution to prevent any unintentional spread of fungal pathogen between study sites.

Each day following a successful capture, we used TRX-2000NB receivers (Wildlife Materials) and Yagi antennas (Models F151-3FB and F152-3FB) to locate transmittered females at the current day-roost tree. Bats were tracked daily for the life of the transmitter or until it dropped from the bat. A Garmin eTrex-10 handheld global positioning system was used to record all roost tree locations. Once a roost tree was located, and if the tree itself was feasible to survey (i.e. roost entrance within mist net height, no obstructing trunk branches), nets were deployed around the tree in a circular fashion to capture as many individuals within the colony as possible (Johnson et al. 2012).

At each confirmed roost tree, vegetative data collection (Silvis et al. 2012) included species, diameter at breast height $(\mathrm{DBH}, \mathrm{cm})$, total tree height $(\mathrm{m})$, roost entrance height $(\mathrm{m})$, decay class (1: alive, 2: declining; 3: dead c 4: loose bark , 5: clean; 6: broken top; 7: stump), canopy class (emergent: a young tree not yet full grown; dominant: crown of the tree is among the dominant in the stand; mid story: a mature tree that takes up most of the general canopy but is overshadowed by dominant trees; suppressed: receives no direct light and is completely overshadowed by all other trees), percent canopy cover (average of 4 densiometer readings in each cardinal direction) at the base of the tree, percent bark remaining, and basal area (factor 10). To help determine characteristics of surrounding trees relative to each known roost, we used the 4 point-quarter system (Silvis et al. 2012). For each of the 4 potential roost trees selected in each cardinal direction quadrant, we recorded tree species, distance to roost tree $(\mathrm{m}), \mathrm{DBH}$, total tree height, decay class, canopy class, and whether roosting opportunities existed (bark/cavity). To investigate trends between used day-roost trees and available potential roost trees in the forest stand, we recorded potential roosts (i.e. trees with exfoliating bark, cavities, or other visible defects) by species along a random transect $(20 \mathrm{~m}$ wide $\times 10 \mathrm{~m}$ long) emanating from the roost location (Ford et al. 2006b, Silvis et al. 2012). All data collected for this study are available in an associated data release (Hyzy et al. 2019).

\subsection{Analytical methods}

Comparing used roost tree parameters with both selected and random available roost trees is accepted as a valid method to assess evidence regarding which characteristics of trees are associated with roost selection (Silvis et al. 2012, 2014, Clement \& Castleberry 2013). We used an information theoretic approach (IT) coupled with conditional logistic regression (Therneau \& Grambsch 2000) to compare individual roost tree characteristics to the 4 nearest neighboring and available trees (Anderson \& Burnham 2002, Silvis et al. 2012). We used the 'clogit' function in the package 'survival' (Therneau \& Grambsch 2000) to examine candidate models representing individual tree characteristics (see Table 1). Site (Governor Dodge, Black River, or Sandhill) was included as a strata in all models. We ranked models using Akaike's information criterion corrected for small sample sizes $\left(\mathrm{AIC}_{\mathrm{C}}\right)$, delta $\mathrm{AIC}_{\mathrm{C}}(\Delta)$, and Akaike's weights $\left(w_{i}\right)$ (Burnham \& Anderson 2002). We considered models with $\Delta \leq 2$ to have sufficient empirical support among all models. 
Preliminary data exploration prior to analyses included checking for overdispersion in the global model and correlations across variables, as well as a variance inflation factor (VIF) analysis (Zuur et al. 2010). The diagnostic tests did not identify overdispersion or collinearity between variables. However, we discovered a weak positive correlation between $\mathrm{DBH}$ and tree height $(\mathrm{r}=0.652)$ as well as a weak negative correlation between canopy class and tree height $(\mathrm{r}=-0.613)$. All other correlation coefficients were $<0.60$. We retained $\mathrm{DBH}$ and canopy class, which are relative measures of tree size and height, and removed actual tree height as a measure (Johnson et al. 2012). Due to small sample sizes in the emergent and midstory canopy classes, we combined all classes into 2 categories for logistic regression analyses: dominant $=1$ and emergent/suppressed/ midstory $=0$. For the conditional regression models, we categorized tree species as maple, oak, aspen, or other (where other included unidentifiable snags and species that were only used once or twice, i.e. Pinus spp., American basswood Tilia americana, black walnut Juglans nigra) to assist with model convergence. Post-hoc we used a chi-square Goodness of Fit test for each site to compare the species of used trees to the species of available trees (without lumping trees into categories).

To assess the social structure of the bat population, we conducted social network analyses using the 'igraph' (Csardi \& Nepusz 2006) and 'tnet' (Opsahl 2009) packages in $R$ (R Core Team 2018). Following the methods of Ford et al. (2016), we defined a maternity colony as females and juveniles using the same trees for day roosting during the same time period. Not all bats were observed for equal lengths of time because of radio-tag failure, capture date (not all bats were captured on the same date), and weather. Furthermore, not all bats in a network were captured and tagged. Therefore, we reduced connections to a binary (yes or no) variable to avoid potential bias rather than weighting connections by frequency of use (Goodreau et al. 2009).

We assessed roost network structure using mean degree, network degree centralization, and network density. Centralization scores are the ratio of the sum of the differences between the centrality scores of the most central point and all other points to the maximum possible sum of differences (i.e. larger values indicate that one vertex is more connected than the others, whereas smaller values indicate that all vertices are equally connected; Freeman 1978, Wasserman \& Faust 1994). Network degree is the average number of contacts (i.e. other bats an individual shared a roost tree with at least once), with higher degree values indicating more contacts an individual has with other individuals in the network. Closely related to network degree is network density, the ratio of the number of connections between nodes to the numbers of all possible connections (Wasserman \& Faust 1994). Increasing values indicate that individual nodes in the network are more connected (i.e. have interactions with more individuals) than in networks with lower density values. We calculated the minimum convex polygon (MCP) home range size for each of the 4 networks using the 'mcp' function in the R package 'adehabitat' (Calenge 2006). All analyses were conducted in the $\mathrm{R}$ statistical program (version 1.01.36; R Core Team 2018).

\section{RESULTS}

We captured 40 adult females and 6 adult male MYSE during the summer field seasons of 2015 and 2016, from May 20 to June 29, across 3 maternity sites (GD, SH, BR). Of those females, 23 were pregnant or lactating, and the remaining 17 were nonreproductive at the time of capture. We caught 9 female and 4 male MYSE at GD in 2015, 8 females at $\mathrm{SH}$ in 2015, and 8 females at BR in 2015. We caught 15 females and 2 males at $\mathrm{SH}$ in 2016. We were not able to capture MYSE at GD or BR during the 2016 season. All females except 1 (an escapee) were affixed with radio transmitters and tracked for an average of $7.2 \mathrm{~d}$, excluding 6 bats with transmitters that failed 1 to $2 \mathrm{~d}$ after attachment and did not provide movement data.

We were able to confirm 53 trees consisting of 9 species as day roosts based on 94 total relocation events. Tagged females used 6 day-roost trees at GD in 2015, 13 trees at SH in 2015, 16 trees at BR in 2015, and 17 trees at SH in 2016. Overall, female bats used 1 to 6 roost trees during the survey period (Fig. 2). The best supported model differentiating used day roosts from nearby available trees was the full model including all variables (Table 1). The top model accounted for $53 \%$ of the model weight and was an improvement over the null model, which assumed random selection relative to the covariates considered. The top model indicated that the odds of a tree being used by a bat increased for dominant trees versus trees in other canopy classes, trees in later decay stages, and trees with larger DBH (Table 2). Although tree species was included in the top model, the odds of use overlapped zero for all categories. Overall, roost trees were larger and more decayed than surrounding trees. Average 


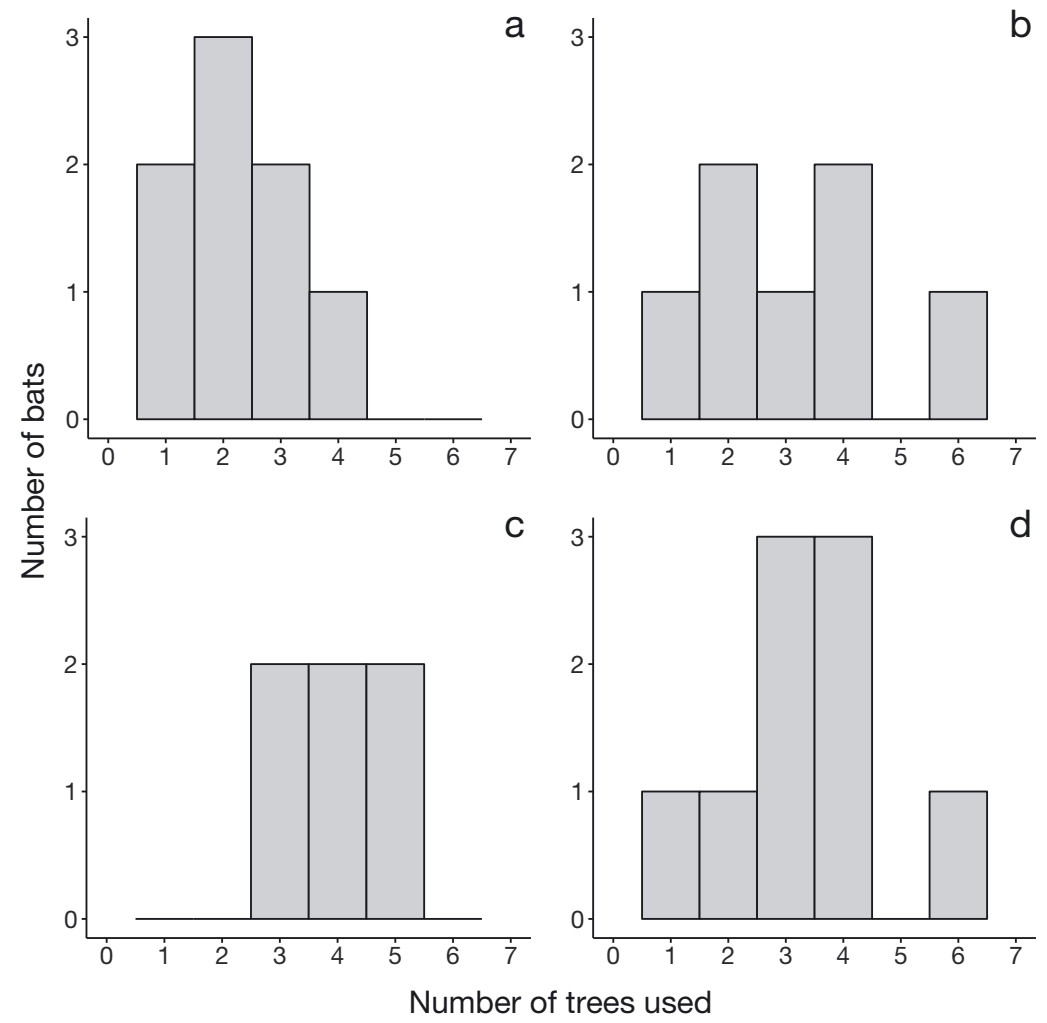

Fig. 2. Number of trees used by female northern long-eared bats Myotis septentrionalis at 3 sites in Wisconsin over the summer during the pregnancy, parturition, and non-volant juvenile part of the maternity season. (a) Governor Dodge State Park in 2015, (b) Black River State Forest in 2015, and Sandhill Wildlife Area in (c) 2015 and (d) 2016

DBH of used day roosts across all sites and years was approximately $32.9 \pm 12 \mathrm{~cm}$ (mean $\pm \mathrm{SE}$ ) versus $30.4 \pm$ $14 \mathrm{~cm}$ for available trees, and average decay state was $3.4 \pm 2$ versus $2.8 \pm 2$ for available trees. Roughly $70 \%$ of roost trees were in the dominant category versus b $59 \%$ of available trees. Finally, 56, 15, and $9 \%$ of used trees were classified as oaks, aspens, and maples, respectively, versus 70,10 , and $9 \%$ of available trees. Of the 53 day roosts located, 29 were under exfoliating bark, 21 were in cavities or crevices, and 3 were unknown. Roosting locations were on average $7.9 \mathrm{~m}$ high on the roost tree. A summary of all variables measured for all used and available day-roost trees across all sites is provided in Table $\mathrm{S} 1$ in the Supplement at www.int-res.com/ articles/suppl/n041p055_supp.pdf.

Total number of tagged bats found occupying the same tree at one time ranged from 1 to 7 . When emergence counts could be conducted, 1 to 30 bats were observed exiting roost trees, with an average of 12 bats sharing 1 tree at a given time. Some females roosted in different trees every day, whereas others returned to the same day roost for up to $4 \mathrm{~d}$ consecutively. On average, females switched roosts every $1.45 \mathrm{~d}$.

Overall, we were able to calculate roost-network metrics for 4 distinct maternity colonies, 1 at BR in 2015, 1 at GD in 2015, and 1 each in 2015 and 2016 at SH, as well as MCPs of the colonies (Fig. 3, Table 3). Estimated MCP size for a network ranged from approximately 4.1 to 8.9 ha, and network centrality and network density were highest at GD and SH in 2015 and lowest at the 2 larger networks (SH in

Table 1. Rankings of models based on $\mathrm{AIC}_{\mathrm{C}}$. Models were used to compare characteristics of day-roost trees used by female northern long-eared bats Myotis septentrionalis to unused potential trees nearby at 3 field sites in Wisconsin (Governor Dodge State Park, Sandhill Wildlife Area, and Black River State Forest) across 2 field seasons in 2015 and 2016. Models are listed with the number of parameters $(k)$, Akaike's information criteria value corrected for small sample sizes $\left(\right.$ AIC $\left._{c}\right)$, difference in $\mathrm{AIC}_{\mathrm{c}}$ value between the top model and $i^{\text {th }}$ model $\left(\Delta_{i}\right)$, and model weight $\left(w_{i}\right)$. DBH: diameter at breast height

\begin{tabular}{|c|c|c|c|c|}
\hline Model & $k$ & $\mathrm{AIC}_{\mathrm{c}}$ & $\Delta_{i}$ & $W_{\mathrm{i}}$ \\
\hline Full model & 7 & 236.37 & 0.00 & 0.53 \\
\hline DBH, Decay stage, Canopy class (Dominant/Midstory vs. Emergent/Suppressed) & 4 & 238.53 & 2.16 & 0.18 \\
\hline DBH, Decay stage, Tree species (Maple, Oak, Other vs. Aspen) & 6 & 239.64 & 3.27 & 0.10 \\
\hline Decay stage & 2 & 240.61 & 4.25 & 0.06 \\
\hline DBH, Decay stage & 3 & 240.89 & 4.53 & 0.05 \\
\hline $\begin{array}{l}\text { Tree species (Maple, Oak, Other vs. Aspen), Canopy class (Dominant/Midstory vs. } \\
\text { Emergent/Suppressed) }\end{array}$ & 5 & 242.37 & 6.00 & 0.03 \\
\hline Canopy class (Dominant/Midstory vs. Emergent/Suppressed) & 3 & 242.48 & 6.12 & 0.02 \\
\hline $\mathrm{DBH}$ & 2 & 243.02 & 6.66 & 0.02 \\
\hline Intercept-only model & 1 & 253.77 & 17.40 & 0.00 \\
\hline Tree species (Maple, Oak, Other vs. Aspen) & 4 & 259.15 & 22.78 & 0.00 \\
\hline
\end{tabular}


Table 2. Parameter estimates from the top 3 models comparing used dayroost trees to unused potential trees nearby for female northern long-eared bats Myotis septentrionalis at 3 field sites in Wisconsin (Governor Dodge State Park, Sandhill Wildlife Area, and Black River State Forest) across 2 field seasons in 2015 and 2016. DBH: diameter at breast height; LCI: lower confidence interval; UCI: upper confidence interval

\begin{tabular}{|lrrrrrrr|}
\hline & \multicolumn{3}{c}{ Parameter estimates } & \multicolumn{3}{c|}{ Odds ratios } \\
& Mean & LCI & UCI & Mean & LCI & UCI \\
\hline Intercept & -2.58 & -3.99 & -1.28 & NA & NA & NA \\
DBH & 0.01 & -0.02 & 0.03 & 1.01 & 0.98 & 1.03 \\
Decay stage & 0.30 & 0.11 & 0.50 & 1.35 & 1.12 & 1.65 \\
Maple vs. Aspen & -0.14 & -1.55 & 1.22 & 0.87 & 0.21 & 3.38 \\
Oak vs. Aspen & -0.82 & -1.77 & 0.19 & 0.44 & 0.17 & 1.20 \\
Other vs. Aspen & 0.42 & -0.77 & 1.63 & 1.52 & 0.46 & 5.12 \\
Canopy class & & & & & & \\
(Dominant vs. Emergent/ & 0.99 & 0.16 & 1.86 & 2.69 & 1.17 & 6.43 \\
$\quad$ Midstory/Suppressed) & & & & & & \\
\hline
\end{tabular}

a

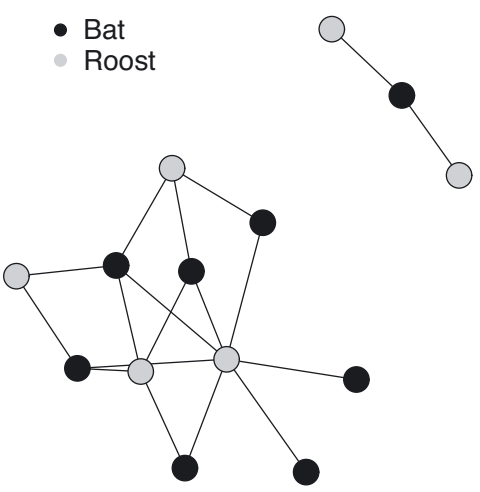

C

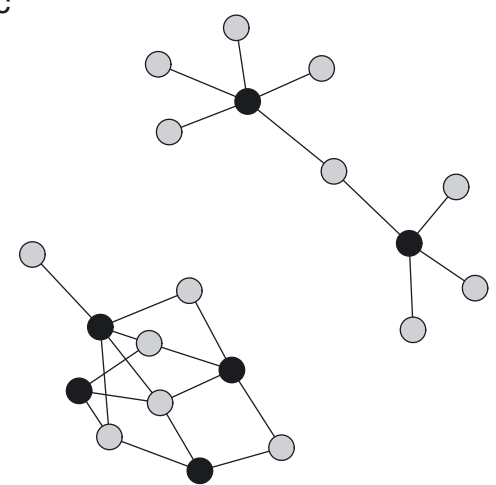

b

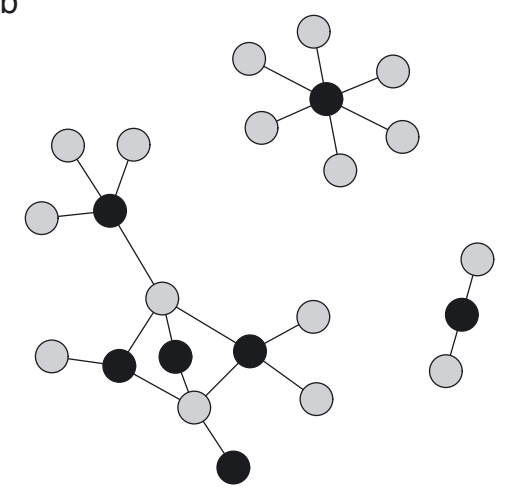

d

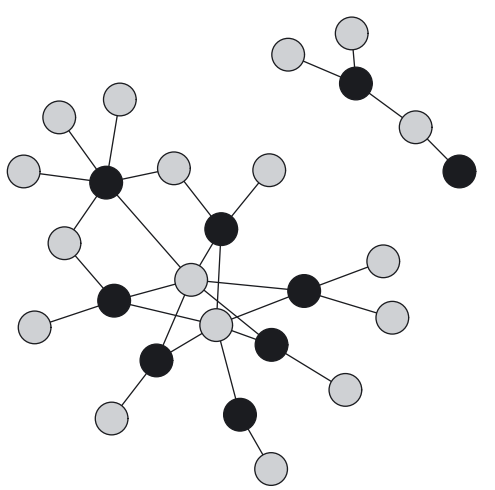

Fig. 3. Scale-free social networks of female northern long-eared bats Myotis septentrionalis tagged and relocated in Wisconsin at (a) Governor Dodge State Park in 2015, (b) Black River State Forest in 2015, and Sandhill Wildlife Area in (c) 2015 and (d) 2016

2016 and BR in 2015). Network degree of centralization was smallest at the largest network ( $\mathrm{SH}$ in 2016), and largest at the smallest network ( $\mathrm{SH}$ in 2015).

At GD, the most commonly used tree species was black locust, and this species was used more than expected based on its general availability in the land- scape $\left(\chi^{2}=18.547, \mathrm{df}=3, \mathrm{p}=0.0003\right.$; Table S2). However, GD sample sizes were small ( $\mathrm{n}=6$ trees), and both locust trees were used by the same bat that was not included in our network analyses. Roost trees in the network at GD included 1 black walnut, 2 northern red oak, and 1 American basswood. The black walnut was located at the center of the network and was used by 7 of 8 bats in the network. Oak species were used proportionally according to their availability at both SH and BR (SH: $\chi^{2}=0.964$, $\mathrm{df}=2, \mathrm{p}=0.617 ; \mathrm{BR}: \chi^{2}=0.472, \mathrm{df}=2$, $\mathrm{p}=0.789$; Tables S3 \& S4). At BR, 2 red maple Acer rubrum, 4 northern red oak, and 1 each of aspen, white oak $Q$. alba, and pin oak $Q$. palustris comprised the roost trees in the network, with the aspen and 1 red maple used by 4 of the 6 bats. At SH in 2015 there were 3 northern red oak, 2 aspen, and 1 oak snag (species undetermined) in the network, and all 4 bats used the snag. Finally at SH in 2016, the largest network included 7 oaks (1 snag, 1 red, 1 pin, and 4 white), 3 red maple, and 2 aspen. The oak snag was the center of the network and used by 4 of the 9 bats at $\mathrm{SH}$.

\section{DISCUSSION}

Our work is the first in-depth study modeling roost selection and social networks for MYSE in the Upper Midwest. Our results from comparing used roost tree characteristics to available trees in the stand support previous studies relating site-level tree characteristics to overall roost availability (Thomas 1988, Sasse \& Pekins 1996, Lacki \& Schwierjohann 2001, Jung et al. 2004, Henderson \& Broders 2008, Jachowski et al. 2016). Models representing $\mathrm{DBH}_{\text {, decay }}$ stage, tree species, and canopy class best explained differences in the probability of a bat using a tree as a roost. Previous MYSE research supports our findings that this species roosts most often in larger, taller, and more mature trees in later stages of decay 
Table 3. Characteristics of 4 social networks in Wisconsin: Governor Dodge State Park in 2015, Black River State Forest in 2015, and Sandhill Wildlife Area in 2015 and in 2016. MCP: minimum convex polygon. Degree: average number of contacts

\begin{tabular}{|lccccc|}
\hline Site & $\begin{array}{c}\text { Degree of } \\
\text { centralization }\end{array}$ & Degree & Density & $\begin{array}{c}\text { MCP } \\
\text { (ha) }\end{array}$ & $\begin{array}{c}\text { No. of } \\
\text { bats }\end{array}$ \\
\hline Governor Dodge (2015) & 0.52 & 6.51 & 0.34 & 5.18 & 8 \\
Sandhill Wildlife Area (2015) & 0.70 & 3.00 & 0.67 & 4.10 & 4 \\
Sandhill Wildlife Area (2016) & 0.19 & 2.63 & 0.11 & 8.93 & 9 \\
Black River State Forest (2015) & 0.32 & 2.65 & 0.22 & 8.00 & 6 \\
\hline
\end{tabular}

availability and condition of quality day roost opportunities tend to be the most widely accepted contributing factors for selection despite the tree species pool of roosts therein. For example, oak snags were located at the center of 2 of the 4 bat networks and their use was consistent with research from the southern Appalachians (O'Keefe 2009), indicative of their importance to maternity colonies in some forest conditions. Nonetheless, results from the secondary

(Thomas 1988, Sasse \& Pekins 1996, Lacki \& Schwierjohann 2001, Jung et al. 2004, Pysllakis \& Brigham 2005). Johnson et al. (2009) found that MYSE in the central Appalachia Region used trees and snags that were smaller in diameter and in higher canopy classes within recently burned forests, but in unburned, uncut stands, bats selected trees of greater size and decay stage, as expected. Numerous MYSE studies have shown that trees with these characteristics tend to have greater amounts of quality roosting habitat (e.g. exfoliating bark, cavities, crevices), and the presence of more trees with these characteristics within a stand increases overall suitable roost habitat availability for these bats (Thomas 1988, Jung et al. 2004, Henderson \& Broders 2008, Ford et al. 2016).

For MYSE and most other temperate bats, sufficient solar radiation is a crucial habitat requirement for female bats during the reproductive period to satisfy thermoregulatory needs during the lactation period (Silvis et al. 2016). As a result, roosts are typically higher in the canopy or in trees that are in more open-canopied forests (Pysllakis \& Brigham 2005, Garroway \& Broders 2008, Johnson et al. 2012). This requirement may vary with regional conditions. In southern regions, where the climate is generally warmer, females may not be as dependent on opencanopied roosting areas to meet their energy demands (Silvis et al. 2012). Although variable, average canopy cover at roost tree sites across all sites and years in our study was relatively low, i.e. $69.3 \%$ $( \pm 25.7 \mathrm{SE})$. This is similar to studies in more northern climates (Garroway \& Broders 2008), but contrasts with studies conducted farther south where canopy cover often exceeded $80 \%$ (Ford et al. 2006b, Silvis et al. 2012).

The role that tree species composition plays in MYSE roost selection varies in the literature and clearly depends on local forest composition and community characteristics (Silvis et al. 2016). However, analysis of roost selection comparing proportions of used day roost trees to available trees in the stand revealed that at 2 field sites ( $\mathrm{SH}$ and $\mathrm{BR}$ ), roost tree species were used in proportion to their availability. At GD, black locust trees were used more than expected based on stand availability, although this result was associated with use by 1 individual not associated with the network. Similar studies of MYSE in eastern North America have documented selection of black locust as roost trees. Black locust are a longlasting and cavity-supporting species, either suppressed in the mid-story or occasionally as a canopydominant bole or snag, thereby supporting consistent and stable roosting areas for bats across multiple seasons (Menzel et al. 2002, Ford et al. 2006b, Johnson et al. 2009, Silvis et al. 2012). Black locust trees are native primarily in the central and southern Appalachians throughout the Ohio River Valley, but are considered a non-native invasive species in Wisconsin and much of the Upper Midwest. Both SH and BR are actively managed forests. The $\mathrm{SH}$ site is primarily managed for wildlife habitat and timber production, whereas BR is extensively managed for timber production and invasive species control. At both sites, black locust either did not become established or was removed during forest management actions. Alternatively, as a state park, forest management at GD is minimal. Therefore, once established the black locust trees have maintained and increased their distribution locally when environmental conditions allow, i.e. following large canopy gap creation or oldfield succession.

Network centrality and network density values were higher in the 2 colonies with the smallest estimated areas (GD and SH in 2015), possibly reflecting better quality habitat as observed by Ford et al. (2016), who found that prescribed burning in central Appalachian forests increased the suitability of residual trees and snags by opening the canopy, increasing solar radiation and reducing foraging clutter. In 
2016, the colony at SH occupied the largest area of any of the observed colonies based on the MCPs and was the least centralized, indicating frequent roost switching, infrequent repeated use of individual day roosts, and low overlap of tagged bats at a given day roost (Table 3). Although day-roost conditions in the landscape at $\mathrm{SH}$ possibly were less optimal than at BR or GD, paradoxically, our larger sample size of tracked bats at SH in 2016 may have led to larger estimates of home range size and decentralization. Regardless, the roost-network areas we observed at all 3 sites were consistent with those in optimal MYSE habitat in the central Appalachians (Johnson et al. 2012), but smaller than the areas observed by Silvis et al. (2014) in the lower Ohio River Valley. As such, it appears that irrespective of the study site, day-roost abundance and suitability was sufficient for MYSE locally at the time of this study.

Extensive monitoring by the Wisconsin Department of Natural Resources, coupled with the results from this study provides crucial information regarding maternal roost use by MYSE in this region. For future research investigating maternal roost selection of MYSE in Wisconsin and the surrounding Upper Midwest, consideration of a number of variables not measured in this project would strengthen overall knowledge and support for ecological data on this species. For example, capture rates were low most nights, and obtaining a sufficient sample size was difficult. In Europe, the use of acoustical lures to attract bat species to netting sites has proven a valid method to increase overall capture success (Hill \& Greenway 2005). This approach is now emerging as a potential sampling tool in North America (Quackenbush et al. 2016). Furthermore, temporal differences in female MYSE roosting behavior, i.e. number of bats within a roost and rates of roost-switching, throughout the maternity season have been demonstrated in previous studies (Garroway \& Broders 2008, Silvis et al. 2012, 2014). However, within the context of Wisconsin, the phenology would be largely the same, and our data collection took place within the confines of the time period when maternity colonies would be intact in June and July prior to fall migration and colony dispersal. Therefore, temporal differences were not a variable considered for this project owing to our overarching aim of describing roost types and conditions, a variable that is largely constant over the summer for MYSE (Johnson et al. 2009, Silvis et al. 2015a). Expanding on this study with a larger sample size and the addition of seasonal variation as a variable would further expand our knowledge of this species in Wisconsin and the sur- rounding Upper Midwest, particularly if assessed relative to stand-level or landscape-level forest condition and composition (Silvis et al. 2015a,b). Anecdotal evidence from the central Appalachians and midAtlantic regions following the introduction of WNS indicate that whereas pre-WNS day-roost selection relative to tree species and surrounding stand conditions did not change, MYSE maternity colonies used increasingly smaller trees as colony sizes decreased (Muthersbaugh 2018).

The northern long-eared bat is currently facing severe population declines because of WNS, coupled with previous stressors including habitat loss and to a lesser extent, wind-energy development (Barclay \& Kurta 2007, Allison et al. 2019). Currently there are no viable treatments for WNS. Therefore, mitigation strategies focusing on controllable stressors such as maintaining the availability of roosting opportunities through forest management practices would be beneficial. The US Fish and Wildlife Service declined to determine critical habitat for this species based on research suggesting the species is opportunistic in terms of roost selection and is able to use a variety of roost habitats. Limiting hardwood timber harvest or management during the summer season, and retaining snags and larger DBH trees, and trees in later stages of decay could minimize or potentially avoid ESA-regulated take of MYSE and possibly mitigate detrimental effects on MYSE populations as well as other species not currently under any regulatory guidance during the summer reproductive season (Silvis et al. 2016). Managing for availability of maternal roosts during the reproductive period for MYSE may increase individual survivorship entering into winter hibernation, which may in turn mitigate the detrimental impact of WNS on populations overall at least in some small part.

Acknowledgements. This project was supported by the United States Geological Survey. E. M. Meyer and J. J. Meyer assisted in field work and data collection for this study. We thank W. L. Fisher for review comments and contributions to this manuscript. Use of trade, firm, or product names is for descriptive purposes only and does not imply endorsement by the U.S. Government.

\section{LITERATURE CITED}

Allison TD, Diffendorfer JE, Baerwald EF, Beston JA and others (2019) Impacts to wildlife of wind energy siting and operation in the United States. Issues in Ecology Report No. 21

Anderson D, Burnham K (2002) Avoiding pitfalls when using information-theoretic methods. J Wildl Manag 66:912-916 
Barclay RMR, Kurta A (2007) Ecology and behavior of bats roosting in tree cavities and under bark. In: Lacki MJ, Hayes JP, Kurta A (eds) Bats in forests: conservation and management. Johns Hopkins University Press, Baltimore, MD, p 17-60

Blehert DS, Hicks AC, Behr M, Meteyer CU and others (2009) Bat white-nose syndrome: an emerging fungal pathogen? Science 323:227

Burnham KP, Anderson DR (2002) Model selection and inference: a practical information-theoretic approach, 2nd edn. Springer-Verlag, New York, NY

Caceres MC, Barclay RMR (2000) Myotis septentrionalis. Mamm Species 634:1-4

Calenge C (2006) The package 'adehabitat' for the R software: a tool for the analysis of space and habitat use by animals. Ecol Model 197:516-519

Clement M, Castleberry S (2013) Summer tree roost selection by Rafinesque's big-eared bat. J Wildl Manag 77:414-422

Coleman LS, Ford WM, Dobony CA, Britzke ER (2014) Effect of passive acoustic sampling methodology on detecting bats after declines from white nose syndrome. J Ecol Nat Environ 6:56-64

Csardi G, Nepusz T (2006) The igraph software package for complex network research. InterJournal Complex Systems 1695

Ford WM, Menzel J, Menzel M, Edwards J, Kilgo J (2006a) Presence and absence of bats across habitat scales in the upper coastal plain of South Carolina. J Wildl Manag 70: 1200-1209

Ford WM, Owen SF, Edwards JW, Rodrigue JL (2006b) Black locust (Robinia pseudoacacia) as day-roosts of male northern bats (Myotis septenetrionalis) on the Fernow Experimental Forest, West Virginia. Northeast Nat (Steuben) 13:15-24

Ford WM, Silvis A, Johnson JB, Edwards JW, Karp M (2016) Northern long-eared bat day-roosting and prescribed fire in the central Appalachians. Fire Ecol 12:13-27

Foster R, Kurta A (1999) Roosting ecology of the northern bat (Myotis septentrionalis) and comparisons with the endangered Indiana bat (Myotis sodalis). J Mammal 80: $659-672$

Francl KE (2008) Summer bat activity at woodland seasonal pools in the northern Great Lakes region. Wetlands 28: 117

Francl KE, Ford WM, Sparks DW, Brack V Jr (2012) Capture and reproductive trends of summer bat communities in West Virginia: assessing the impact of white-nose syndrome. J Fish Wildl Manag 3:33-42

Freeman LC (1978) Centrality in social networks. Conceptual clarification. Soc Networks 1:215-239

* Garroway J, Broders H (2008) Day roost characteristics of northern long-eared bats (Myotis septentrionalis) in relation to female reproductive status. Ecoscience 15:89-93

Goodreau SM, Kitts JA, Morris M (2009) Birds of a feather, or friend of a friend? Using exponential random graph models to investigate adolescent social networks. Demography 46:103-125

Henderson LE, Broders HG (2008) Movements and resource selection of the northern long-eared myotis (Myotis septentrionalis) in a forest-agriculture landscape. J Mammal 89:952-963

Henderson L, Farrow L, Broders H (2008) Intra-specific effects of forest loss on the distribution of the forestdependent northern long-eared bat (Myotis septentrionalis). Biol Conserv 141:1819-1828
Hill D, Greenway F (2005) Effectiveness of an acoustic lure for surveying bats in British woodlands. Mammal Rev 35: $116-122$

Jachowski DS, Rota CT, Dobony CA, Ford WM, Edwards JW (2016) Seeing the forest through the trees: considering roost-site selection at multiple spatial scales. PLOS ONE 11:e0150011

Johnson JB, Edwards JW, Ford WM, Gates JE (2009) Northern myotis (Myotis septentrionalis) roost tree selection in a central Appalachian Mountains hardwood forest subjected to prescribed fire. For Ecol Manage 258:233-242

Johnson J, Edwards J, Ford WM (2011) Nocturnal activity patterns of northern myotis (Myotis septentrionalis) during the maternity season in West Virginia (USA). Acta Chiropt 13:391-397

Johnson J, Ford WM, Edwards J (2012) Roost networks of northern myotis (Myotis septentrionalis) in a managed landscape. For Ecol Manage 266:223-231

Jung T, Thompson I, Titman R (2004) Roost site selection by forest-dwelling male myotis in central Ontario, Canada. For Ecol Manage 202:325-335

Kunz T, Lumsden L (2003) Ecology of cavity and foliage roosting bats. In: Kunz TH, Fenton MB (eds) Bat ecology. University of Chicago Press, Chicago, IL, p 3-89

* Lacki M, Schwierjohann J (2001) Day-roost characteristics of northern bats in mixed mesophytic forest. J Wildl Manag 65:482-488

*Lacki M, Cox D, Dickinson M (2009) Meta-analysis of summer roosting characteristics of two species of myotis bats. Am Midl Nat 162:318-326

Kenzel M, Owen S, Ford WM, Edwards J, Wood P, Chapman B, Miller K (2002) Roost selection by northern longeared bat (Myotis septentrionalis) maternity colonies in an industrial forest of the central Appalachian Mountains. For Ecol Manage 155:107-114

Muthersbaugh MS (2018) Seasonal activity patterns of bats in the central Appalachians. MS Thesis, Virginia Polytechnic Institute and State University, Blacksburg, VA

O'Keefe JM (2009) Roosting and foraging ecology of forest bats in the southern Appalachian Mountains. PhD Dissertation. Clemson University, Clemson, SC

Opsahl T (2009) Structure and evolution of weighted networks. PhD thesis, Queen Mary College, University of London, p 104-122

Owen SF, Menzel MA, Ford WM, Edwards JW, Chapman BR, Miller KV, Wood PB (2002) Roost tree selection by maternal colonies of northern long-eared myotis in an intensively managed forest. USDA Forest Service General Technical Report-NE-292

*Patriquin KJ, Leonard ML, Broders HG, Ford WM, Britzke ER, Silvis A (2016) Weather as a proximate explanation for fission-fusion dynamics in female northern longeared bats. Anim Behav 122:47-57

* Pauli B, Badin H, Haulton G, Zollner P, Carter T (2015) Landscape features associated with the roosting habitat of Indiana bats and northern long-eared bats. Landsc Ecol 30:2015-2029

* Perry R, Thill R (2007) Roost selection by male and female northern long-eared bats in a pine-dominated landscape. For Ecol Manage 247:220-226

*Psyllakis JM, Brigham RM (2006) Characteristics of diurnal roosts used by female Myotis bats in sub-boreal forests. For Ecol Manage 223:93-102

* Quackenbush H, D'Acunto LE, Flaherty EA, Zollner PA (2016) Testing the efficacy of an acoustic lure on bat 
mist-netting success in North American central hardwood forests. J Mammal 97:1617-1622

R Core Team (2018) R: a language and environment for statistical computing. R Foundation for Statistical Computing, Vienna. www.r-project.org

Reynolds R, Powers KE, Orndorff W, Ford WM, Hobson C (2016) Changes in Myotis septentrionalis (northern longeared bat) capture rates and demographics in western Virginia; pre and post white-nose syndrome. Northeast Nat (Steuben) 23:195-204

Sasse DB, Pekins PJ (1996) Summer roosting ecology of northern long-eared bats (Myotis septentrionalis) in the White Mountain National Forest. In: Barclay RMR, Brigham RM (eds) Bats and forests symposium: October 19-21, 1995, Victoria, British Columbia, Canada, p 91-101

Silvis A, Ford WM, Britzke E, Beane N, Johnson J (2012) Forest succession and maternity day roost selection by Myotis septentrionalis in a mesophytic hardwood forest. Int J For Res 2012:1-8

Silvis A, Ford WM, Britzke E, Johnson J (2014) Association, roost use, and simulated disruption of Myotis septentrionalis maternity colonies. Behav Processes 103:283-290

Silvis A, Ford WM, Britzke E (2015a) Day-roost tree selection by northern long-eared bats - What do non-roost

Editorial responsibility: Anna Nekaris,

Oxford, UK tree comparisons and one year of data really tell us? Glob Ecol Conserv 3:756-763

Silvis A, Ford WM, Britzke ER (2015b) Effects of hierarchal roost removal on northern long-eared bat (Myotis septentrionalis) maternity colonies. PLOS ONE 10:e0116356

Silvis A, Perry RW, Ford WM (2016) Relationships of three species of white-nose syndrome-impacted bats to forest condition and management. US Forest Service Southern Research Station General Technical Report SRS-214, Ashville, NC

* Therneau TM, Grambsch PM (2000) Modeling survival data: extending the Cox Model. Springer, New York, NY

Thomas DW (1988) The distribution of bats in different ages of Douglas-fir forests. J Wildl Manag 52:619-626

Wasserman S, Faust K (1994) Social network analysis: methods and applications.Cambridge University Press, Cambridge

Willis CKR, Brigham RM (2004) Roost switching, roost sharing, and social cohesion: forest-dwelling big brown bats, Eptesicus fuscus, conform to the fission-fusion model. Anim Behav 68:495-505

* Zuur A, Leno E, Elphick C (2010) A protocol for data exploration to avoid common statistical problems. Methods Ecol Evol 1:3-14

Submitted: May 30, 2019; Accepted: October 24, 2019

Proofs received from author(s): December 20, 2019 